УДК 94(929):930.1

\title{
“У ЖИТТІ ВЧЕНОГО ГОЛОВНІ БІОГРАФІЧНІ ФАКТИ - КНИГИ”: ОГЛЯД НАУКОВИХ ДОСЛІДЖЕНЬ ПРОФЕСОРА СТЕПАНА КАЧАРАБИ
}

\author{
Руслан СІРОМСЬКИЙ \\ Львівський національний університет імені Івана Франка \\ кафедра нової та новітньої історії зарубіжних країн \\ вул. Університетська 1, Львів, 79000, Україна \\ e-mail: sir.ruslan@yahoo.com
}

\begin{abstract}
Здійснено огляд наукових напрацювань професора Степана Качараби - авторитетного дослідника історії української еміграції, автора численних наукових публікацій з історії України, історичного краєзнавства та світової історії.

Становлення С. Качараби як науковця розпочалося у другій половині 1980-х років і пов'язане з підготовкою кандидатської дисертації, присвяченої українській еміграції з Галичини та Північної Буковини наприкінці XIX - початку XX ст. Значний вплив на формування наукового світогляду молодого дослідника справив професор Степан Макарчук, науковий керівник під час написання кандидатської, а згодом - консультант докторської дисертації. Загалом, серед порушених у студіях вченого проблем варто виокремити такі аспекти, як напрямки еміграції із західноукраїнських земель, еміграційна політика та законодавство країн поселення українців, організація еміграційної політики у Львові та в Західній Україні загалом, суспільна опіка над емігрантами та ін.

Науково-організаційна діяльність С. Качараби - перебування на посаді заступника декана історичного факультету (1990-1994), завідувача катедри історичного краєзнавства (1998-2008) та завідувача катедри нової та новітньої історії зарубіжних країн Львівського університету (від 2008 p.).

Ключові слова: дисертація, історія еміграції, історичне краєзнавство, монографія, історія зарубіжних країн.
\end{abstract}

Ім'я доктора історичних наук, професора Степана Петровича Качараби відоме широкому колові громадськости й асоціюється із дослідженнями історії української еміграції. Він - відомий український історик, автор понад півтори сотні наукових і навчально-методичних праць, зокрема декількох монографій. Запорукою наукових звершень ученого стали працьовитість, наполегливість, сила духу, впевненість у собі, відповідальність та принциповість, що поєднувалися 3 такими загальнолюдськими рисами, як почуття гідности, доброзичливість $\mathrm{i}$ порядність.

Наукове сходження С. Качараби пов'язане з історичним факультетом Львівського університету, де він пройшов шлях від лаборанта до завідувача катедри. Загалом, науково-педагогічний шлях С. Качараби можна поділити на чотири періоди. 
ISSN 2078-6077. Наукові зошити історичного факультету Львівського університету. 2018-2019. Випуск 19-20. Proceedings of History Faculty of Lviv University. 2018-2019. Issue 19-20.

Перший період (1985-1990) - від закінчення історичного факультету Львівського університету до захисту кандидатської дисертації. Із серпня 1985 р. С. Качараба почав працювати у Львівському університеті на посаді старшого лаборанта катедри історії СРСР. Відповідальність і вміння працювати зі студентами не залишилися непоміченими і у вересні 1987 р. його за конкурсом обрали на посаду асистента тодішньої катедри історії УРСР, котра від 1989 р. стала називатися катедрою історії та етнографії України ${ }^{1}$. Одночасно 3 викладацькою діяльністю в університеті Степан Петрович працював штатним працівником (за сумісництвом) історичної секції Малої академії наук.

Формуванню наукового світогляду майбутнього вченого сприяли лекції, дослідження та особистий приклад професора, а протягом 1976-1994 pp. декана історичного факультету Степана Макарчука (1930-2014). Саме Степан Арсентійович спонукав обдарованого випускника досліджувати проблеми української еміграції зі Східної Галичини та Північної Буковини наприкінці XIX на початку XX ст. У своїх спогадах він відзначав: “Я був науковим керівником Степана Петровича, тож знав його відповідальне ставлення до наукової праці й загалом до виконання службових обов'язків. Мої сподівання С. Качараба виправдав"2.

Перші наукові роботи С. Качараби були виконані й апробовані в межах досліджуваної дисертаційної проблеми і стосувалися причин, організації та напрямків еміграції зі Східної Галичини і Північної Буковини, а також відображення галицької трудової еміграції в українських народних піснях ${ }^{3}$. У 1990 р. С. Качараба успішно захистив у Львівському університеті кандидатську дисертацію на тему "Українська трудова еміграція із Східної Галичини і Північної Буковини наприкінці XIX - початку XX ст. (1890-1914рp.)"4. Офіційними опонентами на захисті виступали професор Юрій Макар (Чернівецький державний університет імені Юрія Федьковича) та Феодосій Стеблій (Інститут суспільних наук АН УРСР - сьогодні Інститут українознавства ім. І. Крип’якевича НАН України). Кандидатська дисертація молодого вченого стала лише першим етапом на шляху подальших студій із історії української еміграції.

Другий період (1990-1998) в науковій біографії С. Качараби розпочався після захисту кандидатської дисертації і пов'язаний з активною педагогічною,

\footnotetext{
${ }^{1}$ Костянтин Кондратюк, Спомини і роздуми історика (Львів: ЛА “Піраміда”, 2014), 41.

${ }^{2}$ Степан Макарчук, Побачене, почуте, пережите: Мемуарні мініатюри (Київ: Атіка, 2015), 189.

${ }^{3}$ Степан Качараба, “Трудова західноукраїнська еміграція в кінці XIX - на початку XX ст.: питання історичного аналізу,” Матеріали міжнародної конференції “Еміграція населення західноукраїнських земель до Північної Америки на рубежі XIX-XX cm. ї̈ роль в освоснні Канадського Заходу" (Чернівці, 1990), 72-75.

${ }^{4}$ Степан Качараба, “Українська трудова еміграція із Східної Галичини і Північної Буковини наприкінці XIX - початку XX ст. (1890-1914рр.)” (Автореф. дис. канд. іст. наук, Львівський державний університет імені Івана Франка, 1990), 16 с.
} 
ISSN 2078-6077. Наукові зошити історичного факультету Львівського університету. 2018-2019. Випуск 19-20. Proceedings of History Faculty of Lviv University. 2018-2019. Issue 19-20.

науковою та адміністративною роботою. Упродовж 1990-1994 pр. він заступав посаду заступника декана історичного факультету (у той час заступник відповідав за різні напрямки роботи - навчально-методичну, наукову, виховну). Одночасно молодий науковець працював асистентом на катедрі історії та етнографії України, а від 1992 р. - на посаді доцента цієї ж катедри (тоді ж отримав звання доцента) $)^{5}$.

Особливістю наукової праці того часу стала поступова деідеологізація історії, заповнення “білих плям” минулого та укладення нових програм для шкіл і вищих навчальних закладів. Роль львівських істориків у цій ділянці роботи годі переоцінити, позаяк, за визначенням Ярослава Дашкевича (1926-2010), профільне міністерство не мало виразного бачення навчання історії України у школах ${ }^{6}$. Тож, у найвідповідальніший час для історичної науки у 1990-х роках Степан Петрович став співавтором низки нових програм з історії України та всесвітньої історії для загальноосвітніх шкіл та вищих навчальних закладів ${ }^{7}$.

На основі проведених наукових досліджень вчений розробив навчальні спецкурси для студентів, а саме "Українська еміграція кінця XIX - початку XX ст.”, “Сучасна українська діяспора", "Українці в світі”". У 1992 р. С. Качараба видав дві частини текстів лекцій "Українська еміграція зі Східної Галичини і Північної Буковини в кінці XIX - на початку XX ст."”, а 1995 р. - монографію у співавторстві з Миколою Рожиком "Українська еміграція (1890-1914рр.). Еміграційний рух зі Східної Галичини та Північної Буковини у 1890-1914 pp.”'10. Праця мала помітний резонанс серед громадськости і не втратила свого наукового значення досі.

Третій період (1998-2008) асоціюється з керівництвом катедрою історичного краєзнавства (до 2002 р. називалася катедрою політичної історіі) ${ }^{11}$, до творення якої Степан Петрович долучився з притаманною йому енергією. Відтак катедра

5 Леся Купин, “Качараба Степан Петрович,” Encyclopedia. Львівський національний університет імені Івана Франка: в 2 m. (Львів: ЛНУ імені Івана Франка, 2011), т. 1, 591-592.

${ }^{6}$ Ярослав Дашкевич, Постаті: Нариси про діячів історії, політики, культури (Львів: Львівське відділення ІУАД ім. М. С. Грушевського НАН України; ЛНУ імені Івана Франка, 2006), 687.

7 Див., наприклад: Програма з історії України та всесвітньої історї для загальноосвітніх шкіл (Львів, 1992); Історія Украӥни. Програма курсу для студентів історичного факультету (Львів, 1997); Історія Украӥни. Плани семінарських занять для студентів першого курсу університету (Львів, 1998); Програма курсу “Історія Украӥни” для студентів університету (Львів, 1999).

${ }^{8}$ Історичний факультет Львівського національного університету імені Івана Франка (19402000). Ювілейна книга, упорядники Олексій Вінниченко і Олександр Целуйко, відповідальний за випуск Роман Шуст (Львів: ЛНУ імені Івана Франка, 2000), 59.

${ }^{9}$ Степан Качараба, Украӥнська еміграція зі Східної Галичини і Північної Буковини в кінці XIX - на початку XX ст. Тексти лекиій (Львів, 1992), ч. 1-2.

${ }^{10}$ Степан Качараба і Микола Рожик, Украӥнська еміграція (1890-1914 рр.) Еміграційний рух зі Східної Галичини та Північної Буковини у 1890-1914 рр. (Львів: б. в., 1995), 124 с.

${ }^{11}$ Історичний факультет Львівського начіонального університету імені Івана Франка (19402000), XVII. 
ISSN 2078-6077. Наукові зошити історичного факультету Львівського університету. 2018-2019. Випуск 19-20. Proceedings of History Faculty of Lviv University. 2018-2019. Issue 19-20.

історичного краєзнавства стала першою і єдиною такого спрямування катедрою в Україні. Разом з колегами С. Качараба розробляв теоретичні засади історичного краєзнавства, накресливши подальші вектори його розвитку. Значним досягненням працівників катедри стала підготова навчального посібника 3 історичного краєзнавства ${ }^{12}$. Крім цього, в контексті досліджень української історії С. Качараба опублікував праці, присвячені діяльності українського громадського і політичного діяча Василя Мудрого (1893-1966) ${ }^{13}$, етнодемографічному розвитку Галичини у складі монархії Габсбургів ${ }^{14}$, спільно 3 колегами здійснив наукову редакцію нарису історії Яворівщини авторства краєзнавця Йосипа Гронського (1902-1984) ${ }^{15}$. Сьогодні Степан Петрович $є$ членом Національної спілки краєзнавців України.

Вагоме місце в науковому доробку вченого посідає серія конференцій “ІІторичні пам'ятки Галичини”, що проводиться у Львові від 2001 р.. Крім неї, разом із колегами з Краківського педагогічного університету С. Качараба долучився до організації міжнародної конференції “Львів: місто - суспільство культура” (проводиться від 1992 р. почергово у Львові та Кракові) ${ }^{16}$. Степан Петрович досі єдиний, хто брав участь у всіх чотирнадцяти конференціях цієї серії, опублікувавши в тематичних збірниках дванадцять статтей. Учений $\epsilon$ членом української частини Комісії істориків України та Угорщини. Крім цього, в межах міжнародної співпраці С. Качараба проходив стажування у Вроцлавському, Ягеллонському, Ряшівському (Жешувському) та інших закордонних університетах; брав участь у виконані міжнародних проєктів-грантів.

У середині 1990-х років С. Качараба розпочав працювати над докторською дисертацією, яку 2003 р. успішно захистив в Інституті українознавства ім. I. Крип'якевича НАН України ${ }^{17}$ (рік по тому отримав вчене звання професора). Захисту передувала публікація грунтовної монографії “Еміграція з Західної України”, яка стала підсумком наукових пошуків вченого. Ці пошуки він проводив в архівах Польщі, Білорусі та, звісно, України (опрацював, для

\footnotetext{
${ }^{12}$ Віктор Голубко, Степан Качараба та Алла Середяк, Історичне краєзнавство. Навчальний посібник (Львів: ЛНУ імені Івана Франка, 2006), ч. 1, 180 с.

${ }^{13}$ Степан Качараба, “Василь Мудрий - редактор часопису “Діло” (1927-1935 роки)," Історична пам'ять. Науковий збірник 1 (2007): 78-85; Степан Качараба і Ярослав Комарницький, Василь Мудрий - громадський діяч, політик, публіцист (Дрогобич: Редакційно-видавничий відділ ДДПУ імені Івана Франка, 2009), 240 с.

${ }^{14}$ Степан Качараба, “Етнодемографічний розвиток Галичини за умов австрійського панування,” Галичина: етнічна історія, ред. Степан Макарчук (Львів: ЛНУ імені Івана Франка, 2008), 116-130.

${ }^{15}$ Йосип Гронський, Нарис історії Яворівщини, наук. ред. Віктор Голубко, Степан Качарабп та Аллп Середяк (Дрогобич: Коло, 2008), 218 с.

${ }^{16}$ Кондратюк, Спомини і роздуми історика, 112.

${ }^{17}$ Степан Качараба, Еміграція з Західної Украӥни. 1919-1939 (Автор. дис. докт. іст. наук, НАН України, Інститут українознавства ім. І. Крип’якевича, Інститут народознавства, 2003), $31 \mathrm{c}$.
} 
прикладу, матеріяли з усіх обласних архівів Західного регіону). Науковий консультант професор С. Макарчук згадував: “Ще працюючи над своєю докторською дисертацією, я зауважив, що про еміграцію до Першої світової війни писали I. Франко, А. Андрухович, згодом - А. Шлепаков, еміграція ж міжвоєнного часу серйозно не вивчалась. Отже, запропонував тему, яку претендент у доктори прийняв, серйозно поставившись до ії виконання. Так само читав, дещо критикував частини дисертації. Отже, цього науковця я проводив від аспіранта до професора. У мої старші роки він цього не забуває і $€$ для мене свого роду ще одним приятелем і другом з молодшого покоління..."18.

У докторській монографії С. Качараба дослідив соціяльно-економічні та політичні передумови еміграційного руху в Західній Україні міжвоєнного періоду (Східна Галичина, Західна Волинь, Західне Полісся), еміграційну політику польського уряду, зокрема, іiі національний аспект, масштаби та динаміку еміграційного руху, законодавчі акти Польської держави щодо еміграційних процесів. Водночас дослідник проаналізував формування та розвиток державного еміграційного апарату на західноукраїнських землях, утворення та діяльність громадських об'єднань опіки над емігрантами, розселення західноукраїнських емігрантів, їх соціяльно-економічне та національно-культурну адаптацію у країнах імміграції ${ }^{19}$.

Четвертий період (від 2008 р.) пов'язаний із завідуванням катедрою нової та новітньої історії зарубіжних країн. Більшість попередніх досліджень С. Качараби заторкували українську проблематику в контексті світової історії, до того ж докторська дисертація була захищена за спеціальністю 07.00.02 - всесвітня історія. Спільно із працівниками катедри нової та новітньої історії зарубіжних країн учений підготував програму з курсу “Новітня історія країн Західної Европи і Америки (1918 - початок XXI ст.)"20, став співавтором рекомендованого Міністерством освіти і науки України посібника з історії країн Західної Европи та Північної Америки Нового часу (кінець XV - початок XIX ст.) та практикуму 3 історії Західної Европи та Америки другої половини XX - початку XXI ст. ${ }^{21}$

Загалом, у центрі наукових досліджень Степана Петровича перебували й надалі залишаються проблеми еміграції, серед яких виділимо декілька ключових проблем.

\footnotetext{
${ }^{18}$ Макарчук, Побачене, почуте, пережите, 216.

${ }^{19}$ Степан Качараба, Еміграція з Західної України (1919 - 1939) (Львів: ЛНУ імені Івана Франка, 2003), 416 c.

${ }^{20}$ Програма з курсу "Новітня історія країн Західної Свропи і Америки (1918 - початок XXI cm.)”, укладачі Степан Качараба, Геннадій Кипаренко, Степан Мовчан, Руслан Сіромський, Михайло Швагуляк (Львів: ЛНУ імені Івана Франка, 2010), 58 с.

21 Зоя Баран, Степан Качараба, Руслан Сіромський та Богдан Чума, Iсторія країн Західної Свропи та Північної Америки Нового часу (кінець XV-початок XIX cm.): навчальний посібник, ред. Зоя Баран (Київ: Знання, 2015), 533 с.; Степан Качараба і Руслан Сіромський, Iсторія Західної Європи та Америки другої половини ХХ- початку ХХІ ст.: практикум (Львів: ЛНУ імені Івана Франка, 2015), 293 с.
} 
ISSN 2078-6077. Наукові зошити історичного факультету Львівського університету. 2018-2019. Випуск 19-20. Proceedings of History Faculty of Lviv University. 2018-2019. Issue 19-20.

Отже, одним із аспектів досліджень вченого є перебіг еміграції з окремих воєводств і повітів Західної України. Наприклад, дослідник простежив еміграцію 3 Дрогобиччини і Рогатинщини (проблеми трудової еміграції), Поліського і Волинського воєводств (особливості еміграційної політики, еміграцію німців тощо) $)^{22}$.

Іншим важливим аспектом досліджень стали напрями (географія) трудової i сезонної емітрації із західноукраїнських земель. За понад двадцять років вивчення проблеми в доробку С. Качараби перебувають як загальний аналіз причин і напрямів української еміграції зі Східної Галичини і Північної Буковини наприкінці XIX - першої третини XX ст. ${ }^{23}$, так й еміграція українців у різні куточки світу - від Европи до Америки. Зокрема, дослідник виокремив еміграційні потоки до таких країн, як Росія, Боснія і Герцеговина (у співавторстві зі Степаном Мовчаном) $)^{24}$, Франція ${ }^{25}$, Аргентина (соціяльна характеристика емігрантів) ${ }^{26}$,

${ }^{22}$ Степан Качараба, “Трудова еміграція з Рогатинщини (кінець XIX - початок XX ст.),” Рогатинська земля: історія та сучасність. Матеріали ІІІ наукової конферениії 26 березня 2002 p. (Львів, 2005), 147-156; Степан Качараба, “Еміграція з Поліського воєводства (1919-1939)," Шляхами історії. Науковий збірник історичного факультету ЛНУ ім. Івана Франка на пошану професора Костянтина Кондратюка, упорядник Олексій Сухий (Львів: Видавництво "Піраміда", 2004), 348-364; Степан Качараба, "Еміграційна політика Польщі та ії реалізація у Волинському воєводстві (1921-1939рр.),” Волинська трагедія: через історію до порозуміння. Матеріали Всеукраӥнської наукової конферениї, м. Луцьк, 19-20 червня 2013 року (Луцьк: Східноєвропейський національний університет імені Лесі Українки, 2013), 128-139; Степан Качараба, “Німецька еміграція з Волинського воєводства (1919-1939),” Вісник Львівського університету. Серія історична 51 (2015): 265-274; Степан Качараба, “До питання про еміграцію 3 Дрогобицького повіту наприкінці XIX - початку XX ст.,” Дрогобицький краєзнавчий збірник. Спецвипуск 3 (2017): 82-90.

${ }^{23}$ Степан Качараба, “Напрямки української еміграції зі Східної Галичини і Північної Буковини наприкінці XIX - на початку XX ст.," Вісник Львівського університету. Серія історична 33 (1998): 114-121; Степан Качараба, “Основні риси української трудової еміграції кінця XIX першої третини XX ст.," Заробітчанство як вибір майбутнього: проблеми соціальнопсихологічної адаптачії дітей, батьки яких перебувають на заробітках за кордоном (Львів, 2004), 78-88; Степан Качараба, "Вплив Першої світової війни на еміграцію із Західної України до США,” Перша світова війна у військово-історичному вимірі (до 100-річчя подіi): Збірка матеріалів Міжнародного наукового форуму 26-28 червня 2014 р. (Львів: АСВ, 2014): 66-68.

${ }^{24}$ Степан Качараба, "Еміграція галицьких селян в Російську імперію в кінці ХIX ст.," Украйнський історичний журнал 9 (1990): 30-36; Степан Качараба і Степан Мовчан, “Еміграція галицьких селян в Боснію і Герцеговину наприкінці XIX - на початку XX ст.,” Проблеми слов'янознавства 42 (1990): 66-73.

${ }^{25}$ Степан Качараба, “Трудова еміграція із Західної України у Францію (1919-1939),” Галичина 8 (2002): 95-107.

${ }^{26}$ Степан Качараба, “Еміграція населення Західної України в Аргентину (1919-1939),” Наукові зошити історичного факультету Львівського університету 4 (2001): 184-196; Степан Качараба, “Соціальна характеристика емігрантів з Польщі в Аргентину у міжвоєнний період (1919-1939)," Народознавчі зошити 3 (2001): 433-439; Степан Качараба, "Українська еміграція з Галичини в Аргентину наприкінці XIX - першій третині XX ст.," Етнічна культура українців, ред. Михайло Глушко (Львів: ЛНУ імені Івана Франка, 2006), 82-91; Степан Качараба, “Післямова,” Михайло Василик, Українці Аргентини: історія та сучасність (Львів: Вид-во Українського Католицького Університету, 2009), 248-255. 
ISSN 2078-6077. Наукові зошити історичного факультету Львівського університету. 2018-2019. Випуск 19-20. Proceedings of History Faculty of Lviv University. 2018-2019. Issue 19-20.

Бразилія ${ }^{27}$, США ${ }^{28}$, Канада ${ }^{29}$. Значну увагу у своїх дослідженнях вчений присвятив аналізові особливостей і напрямів сезонової еміграції галицьких і буковинських селян (наприклад, до Німеччини) ${ }^{30}$. Крім еміграції українців, учений проаналізував також еміграційні процеси в середовищі поляків (США) $)^{31}$, німців ${ }^{32}$ та галицьких євреїв (до Аргентини та Палестини) ${ }^{33}$.

Починаючи від 2000-х років у наукових дослідженнях С. Качараби присутній аналіз еміграційної політики та законодавства краӥн поселення (Канада, США, Бразилія, Аргентина) ${ }^{34}$. Значну увагу вчений приділяв вивченню заходів

\footnotetext{
${ }^{27}$ Степан Качараба, “Трудова еміграція із Західної України в Бразилію (1919-1939),” Наукові записки Тернопільського державного педагогічного університету ім. В. Гнатюка. Серія: Історія 1 (2003): 211-221.

${ }^{28}$ Степан Качараба, “3 Галичини до Америки: подорож українського емігранта (кінець XIX початок XX ст.),” Lwów: miasto - spoleczeństwo - kultura 9 (2014): 136-144.

${ }^{29}$ Степан Качараба, “Трудова еміграція із Західної України в Канаду (1919-1939),” Вісник Львівського університету. Серія історична 37, ч. 1 (2002): 350-364.

${ }^{30}$ Степан Качараба, “Сезонна еміграція галицьких і буковинських сільськогосподарських робітників до Німеччини,” Вісник Львівського університету. Серія історична 28 (1992): 57-66; Stepan Kacharaba, "Emigracia sezonowa galiciyskich i bukowińskich robotników rolnych do Niemiec," Chlopi, naród, kultura 5 (1997): 201-211; Степан Качараба, “Сезонна еміграція із Західної України в Німеччину (1919-1939),” Вісник Львівського університету. Серія історична 38 (2003): 219241; Степан Качараба, “Сезонна еміграція зі Східної Галичини в Німеччину у першій третині ХХ ст.," Україна: культурна спадщина, національна свідомість, державність 16 (2008): 207217.
}

${ }^{31}$ Степан Качараба, "Польська еміграція із Західної України до США (1919-1939 рр.)," Украйна - Свропа - Світ. Міжнародний збірник наукових праць. Серія: Історія, Міжнародні відносини 2 (2009): 90-99; Степан Качараба, “Польська еміграція із Західної України до Бразилії у міжвоєнний період,” Украӥна: культурна спадщина, національна свідомість, державність 21 (2015): 113-122.

${ }^{32}$ Степан Качараба, "Німецька еміграція із Західної України у міжвоєнний період (19191939 рр.)," Німиі в історії Волині. Матеріали Міжнародної науково-практичної конферениії. Луцьк, 1-2 жовтня 2015 р. (Луцьк: ПК “Твердиня”, 2016), 212-218.

${ }^{33}$ Степан Качараба, “Еміграція євреїв із Західної України в Аргентину (1919-1939),” Наукові записки Тернопільського державного педагогічного університету ім. В. Гнатюка. Серія: Історія 13 (2001): 135-142; Степан Качараба, "Етапи еміграції євреїв із Західної України в Палестину у 1919-1939 рр.," Дрогобицький краєзнавчий збірник. Спеивипуск до 60-річчя УПА (2002): 326-339; Степан Качараба, "Еміграція євреїв із Західної України в Палестину у 19191939 роках," Украӥна Модерна 7 (2002): 119-140; Stepan Kacharaba, "Emigracja Żydów z Ukrainy Zachodniej do Stanów Zjednoczonych w latach 1919-1939," Świat niepożegnany: Żydzi na dawnych ziemiach wschodnich Rzeczypospolitej w XVIII-XX wieku: praca zbiorowa. Pod redakcją Krzysztofa Jasiewicza (Warszawa: Instytut Studiów Politycznych PAN, 2004), 77-87.

${ }^{34}$ Степан Качараба, "Вплив законодавства США на українську еміграцію (1919-1939рр.),” Питання історії України 4 (2000): 170-175; Степан Качараба, "Вплив законодавства Канади на українську трудову еміграцію з Польщі (1919-1939),” Актуальні проблеми державного управління 5 (2001): 282-291; Степан Качараба, "Вплив законодавства Бразилії на еміграцію із Західної України (1919-1939),” Питання історії України 6 (2003): 144-148; Степан Качараба, “Вплив законодавства Аргентини на еміграцію з Західної України (1919-1939рр.),” Ефективність державного управління. Збірник наукових праць Львівського регіонального інституту державного управління Національної Академії державного управління при президентові 
ISSN 2078-6077. Наукові зошити історичного факультету Львівського університету. 2018-2019. Випуск 19-20. Proceedings of History Faculty of Lviv University. 2018-2019. Issue 19-20.

австрійського, польського, канадського урядів щодо української еміграції $з$ Галичини та Буковини ${ }^{35}$. У публікаціях Степана Петровича також відображена урядова політика щодо еміграції євреїв із західноукраїнських земель ${ }^{36}$.

Значний пласт досліджень складає організація еміграційної політики у Львові та в Західній Україні загалом. У межах цієї проблематики виокремимо студії, присвячені діяльності еміграційних органів Польщі у Західній Україні, зокрема Еміграційного Дому у Львові, Польського еміграційного товариства, Експозитури Еміграційного управління, Львівського представництва Варшавської еміграційної управи, Львівського відділу Сврейського центрального еміграційного товариства “JEAS" ${ }^{\prime 37}$. Дотичні до цієї проблеми статті з історії функціонування мореплавних компаній та участи їх агентури в еміграційному русі ${ }^{38}$.

України 5 (2004): 139-146; Степан Качараба, “Від свободи імміграції до рестрикціонізму: вплив законодавства США на українську еміграцію наприкінці XIX - першій третині XX ст.,” Вісник Львівського університету. Серія історична 39-40 (2005): 300-314; Степан Качараба, “Законодавство Бразилії щодо української еміграції з Галичини наприкінці XIX - першій третині XX ст.,” Міжнародні зв'язки: наукові пошуки і знахідки 16 (2007): 203-216.

${ }^{35}$ Степан Качараба, “Ставлення австрійського уряду до української еміграції з Галичини та Буковини,” Вісник Львівського університету. Серія історична 29 (1993): 88-99; Степан Качараба, “Еміграційна політика Польщі у міжвоєнний період," Наукові зошити історичного факультету Львівського університету 1 (1997): 103-105; Степан Качараба, “Імміграційна політика Канади та iï вплив на українську еміграцію з Польщі (1919-1939рр.)," Питання історії Украӥни 5 (2002): 91-96; Степан Качараба, “Еміграційна політика Польщі та їі реалізація на Західній Україні (19191939),” Проблеми слов'янознавства 52 (2002): 73-86.

${ }^{36}$ Степан Качараба, “Сврейська еміграція в політиці польського уряду у 1919-1939 рр.,” Науковий вісник Чернівещького університету. Історія. Політичні науки. Міжнародні відносини 272. (2005): 143-149; Степан Качараба, "Еміграційна політика польського уряду щодо євреїв у 1919-1939 рр.,” Поляки, українці, білоруси, литовщі у міжвоєнній Польщі (1921-1939). Матеріали міжнародної наукової конференщиї, Дрогобич, 8-9 жовтня 2004 р. (Дрогобич, 2005), $52-63$.

${ }^{37}$ Степан Качараба, “Еміграційний Дім у Львові,” Львів: місто - суспільство - культура 3 (1999): 513-517; Степан Качараба, “Польське еміграційне товариство у Львові (1927-1939 рр.)," Вісник Львівського університету. Серія історична 34 (1999): 479-485; Степан Качараба, “Експозитура Еміграційного уряду у Львові (1923-1932)," Lwów: miasto - społeczeństwo kultura 4 (2002): 333-345; Степан Качараба, "Еміграційні органи Польщі на Західній Україні (1919-1939рр.)," Наукові записки Національного університету “Острозька академія": Історичні науки 2 (2002): 96-105; Степан Качараба, “Львівське представництво Варшавського еміграційного управління (1923-1932),” Вісник Львівської комериійної академії. Серія “Гуманітарні науки” 4 (2002): 124-132; Степан Качараба, “Львівський відділ Сврейського центрального еміграційного товариства “JEAS" (1924-1939)," Проблеми гуманітарних наук. Наукові записки ДДПУ 9 (2002): 172-182; Степан Качараба, “Вплив Варшавського еміграційного синдикату на еміграцію із Західної України (1930-1939)," Наукові зошити історичного факультету Львівського університету 5-6 (2003): 204-210; Степан Качараба, "Експозитура Еміграційного управління у Львові в системі польських еміграційних інституцій,” Lwów: miasto społeczeństwo - kultura 7 (2010): 157-167.

${ }^{38}$ Степан Качараба, "Роль морехідних компаній та їх агентури в еміграційному процесі," Украйнська еміграчія. Історія і сучасність. Матеріали міжнародних наукових конференцій присвячених сторіччю еміграції украйнців до Канади (Львів, 1992), 47-58; Степан Качараба, "Участь морехідних компаній в організації переселення західноукраїнського селянства в Латинську 
ISSN 2078-6077. Наукові зошити історичного факультету Львівського університету. 2018-2019. Випуск 19-20. Proceedings of History Faculty of Lviv University. 2018-2019. Issue 19-20.

Повноту картини еміграції із Західної України формують дослідження, присвячені обставинам еміграції, агітації потенційних емігрантів, творення образу країни поселення, проблема еміграції в діяльності політичних партій та рухів у Галичині, ставлення єврейської громадськости Львова до еміграції в Палестину (у т. ч. політична пропаганда сіоністських партій та об'єднань), позиція ГрекоКатолицької церкви до еміграції українців ${ }^{39}$. У 2014 р. Степан Петрович у співавторстві із Романом Гораком, Зіновієм Яворівським та Василем Кучеруком видали монографію, присвячену Йосипу Олеськову (1860-1903) - ініціяторові й популяризаторові масової еміграції українців до Канади ${ }^{40}$.

Вивчення джерел з історії української еміграції становить окрему когорту досліджень Степана Петровича. Вчений проаналізував значення таких газет, як "Український емігрант" та "Chwila”, документи Центрального державного історичного архіву України у м. Львові, літературні твори сучасників еміграційного руху (наприклад, Андрія Чайковського) ${ }^{41}$. Безумовно, помітну наукову цінність

Америку у міжвоєнний період (1918-1939рр.)," Наукові зошити історичного факультету Львівського університету 2 (1999): 169-181; Степан Качараба, "Роль мореплавних компаній та їх агентури в еміграційному русі на Західній Україні (1919-1939),” Вісник Львівського університету. Серія історична 35-36 (2000): 274-285.

${ }^{39}$ Степан Качараба, "Проблема еміграції в політичній пропаганді галицького москвофільства," Республіканець 1 (1994): 28-31; Степан Качараба, “Оповідання і чутки про еміграцію в Галичині наприкінці XIX - на початку XX ст.," Народознавчі зошити 2 (1999): 150-153; Степан Качараба, “Проблема єврейської прабатьківщини в політичній пропаганді сіоністських партій та об'єднань Західної України,” Історико-культурна спадщина Прикарпаття. Науковий збірник на пошану Петра Арсенича з нагоди його 70-річчя та 45-річчя історико-краєзнавчої діяльності (ІваноФранківськ: Вид-во “Нова Зоря", 2006), 513-525; Степан Качараба, “Ставлення єврейської громадськості Львова до проблеми еміграції в Палестину (1919-1939),” Львів: місто суспільство - культура 6 (2007): 523-535; Степан Качараба, “Греко-католицька церква у ставленні до української еміграції з Галичини наприкінці XIX - на початку XX ст.," Вісник Львівського університету. Серія історична 46 (2011): 116-130; Степан Качараба, "Вплив Першої світової війни на еміграцію із Західної України,” Перша та друга світові війни в історії людства (до 100річчя початку Першої і 75-річчя початку Другої світових воєн): монографія, ред. Сергій Троян (Київ: ДП “НВЦ “Пріоритети”, 2014), 213-226.

${ }^{40}$ Роман Горак, Зіновій Яворівський, Степан Качараба і Василь Кучерук, Йосип Олеськів. Життя і діяльність (Львів: Вид-во “Проман”, 2014), 440 с.

${ }^{41}$ Степан Качараба, "Газета "Український емігрант" як літописець еміграції із Західної України," Матеріали наукової краєзнавчої конференції “Історичні пам'ятки Галичини” (Львів, 2001), 64-70; Степан Качараба, "Газета "Chwila" як джерело до вивчення еміграції євреїв із Західної України в Палестину," Актуальні проблеми державного управління 6 (2001): 310-319; Степан Качараба, “Документи ЦДІА України у Львові про еміграцію із Західної України у Францію (1919-1939)," “Історичні пам'ятки Галичини”. Матеріали II наукової краєзнавчої конференції 21 листопада 2002 р. (Львів: ЛНУ імені Івана Франка, 2003), 55-66; Степан Качараба, “Трудова еміграція з Західної України: історіографія проблеми," Міжнародні зв'язки: наукові пошуки $i$ знахідки 13 (Київ, 2004), 328-337; Степан Качараба, “Документи ЦДІА України у Львові про українську еміграцію до Бразилії наприкінці XIX - на початку XX ст.," “Історичні пам'ятки Галичини" (До 150-річчя від дня народження Івана Франка). Матеріали IV наукової краєзнавчої конференщії 10 листопада 2006 р. (Львів: ЛНУ імені Івана Франка, 2008), 378-386; Степан 
ISSN 2078-6077. Наукові зошити історичного факультету Львівського університету. 2018-2019. Випуск 19-20. Proceedings of History Faculty of Lviv University. 2018-2019. Issue 19-20.

становить відкриття для громадськости щоденника селянина з Покуття Івана Дорундяка, в якому той описав свою подорож 1895 р. до Канади. Після повернення мандрівник популяризував у пресі цю країну як найбільш придатний еміграційний напрям, охарактеризував становище українського селянства в Австро-Угорщині, описав шлях емігранта зі Львова до порту Квебек у Канаді. У “Щоденнику” також міститься значний матеріял про життя і побут перших українських поселенців у канадських Преріях ${ }^{42}$.

Проблема адаптації і сприяння входженню у нове суспільство складають ще один аспект дослідницьких інтересів професора С. Качараби. Зокрема, ключову роль щодо цього відігравала Греко-Католицька церква, котра опікувала українських емігрантів у достатньо важкий для них час пристосування до нових суспільних реалій (Німеччина, Боснія та Герцеговина). Крім того, вчений простежив організацію підтримки емігрантів з боку львів'ян та створених ними опікунських товариств ${ }^{43}$.

Дотичними до зазначеної проблематики є окремі аспекти історії церкви в країнах масового поселення українців - США та Канаді. Найістотнішою проблемою становлення церковної структури була позиція Ватикану щодо організації церковних громад і статусу греко-католицького духовенства. Не менше значення мала і проблема взаємовідносин між священиками з Галичини та Закарпаття. У центрі аналізу - особливості становлення Греко-Католицької церкви у цих країнах, а також загальні тенденції релігійного та обрядового

Качараба, “Документи ЦДІА України у Львові про суспільну опіку Греко-католицької церкви над українською еміграцією у Бразилії та Аргентині (кінець XIX - початок XX ст.),” Iсторичні пам'ятки Галичини. Матеріали V наукової краєзнавчої конференції 12 листопада 2011 р. (Львів: ЛНУ імені Івана Франка, 2011), 203-212; Степан Качараба, “Бразилійський гаразд” Андрія Чайковського: історична реальність чи художній вимисел?” Вісник Львівського університету. Серія історична 48 (2013): 104-114.

${ }^{42}$ Степан Качараба, “Щоденник Івана Дорундяка (До історії української еміграції в Канаду),” Вісник Львівського університету. Серія історична 37, ч. 2 (2002): 128-172; Степан Качараба, “Щоденник Івана Дорундяка як джерело до вивчення української еміграції в Канаду,” "Історичні пам'ятки Галичини”. Матеріали ІІІ наукової краєзнавчої конференції 19 листопада 2004 р. (Львів: ЛНУ імені Івана Франка, 2005), 66-74.

${ }^{43}$ Степан Качараба, “Діяльність греко-католицького духовенства серед сезонних емігрантів у Німеччині (1900-1914),” Вісник Львівської комерційної академії. Серія “Гуманітарні науки” 10 (2011): 188-196; Степан Качараба, “Суспільна опіка Греко-католицької церкви над українською еміграцією в Боснії та Герцеговині (кінець XIX - початок XX ст.," Україна - Свропа - Світ. Міжнародний збірник наукових праць. Серія: Історія, Міжнародні відносини 5, ч. 2 (2011): 275 282; Степан Качараба, “Душпастирська опіка Греко-католицької церкви над українською еміграцією у Боснії та Герцеговині (кінець XIX - початок XX ст.),” Вісник Львівського університету. Серія історична 49 (2013): 130-143; Степан Качараба, “Товариство "Польська опіка над співвітчизниками за кордоном” у Львові (1927-1939)," Історико-політичні проблеми сучасного світу 8 (2001): 110-118; Степан Качараба, "Участь львів'ян в організації опіки над емігрантами (1921-1939)," Lwów: miasto - spoleczeństwo - kultura 5. (2005): 397-407. 
характеру в діяспорі ${ }^{44}$. До слова, історії українських громад у різних державах світу Степан Петрович присвятив декілька енциклопедичних статтей в авторитетних виданнях України ${ }^{45}$.

Огляд наукової роботи Степана Петровича був би неповний, якщо не згадати про його діяльність упродовж 2006-2010 рр. як члена Експертної ради 3 історичних наук Вищої атестаційної комісії у Києві, де професор долучився до експертизи великої кількости дисертаційних праць молодих науковців. Водночас, як авторитетний учений, С. Качараба входив (і досі входить) до спеціялізованих рад із захисту дисертацій з історії у Львівському національному університет імені Івана Франка, Інституті українознавства ім. І. Крип'якевича НАН України та Інституті народознавства НАН України; виступав опонентом на захисті десятків кандидатських дисертацій у наукових установах Львова, Києва, Луцька, Івано-Франківська, Чернівців. Сьогодні вчений $є$ членом оргкомітетів міжнародних і всеукраїнських наукових конференцій та редколегій низки українських періодичних фахових видань, зокрема у Львівському, Прикарпатському, Східноевропейському, Тернопільському університетах. В останні роки С. Качараба керує методологічним семінаром на історичному факультеті Львівського університету.

Професор С. Качараба багато уваги і зусиль приділяє вишколу педагогічних і наукових кадрів. Під його керівництвом уже десятеро аспірантів захистили кандидатські дисертації з актуальних проблем історії України та всесвітньої історії (Оксана Сурмач, Лев Калиняк, Ганна Сіромська, Олександр Дарованець, Ярослав Комарницький, Назар Васьків, Ірина Франків, Ірина Гнідик, Леся Купин, Ганна-Меланія Тичка).

Результати досліджень Степана Петровича відзначені ученими i громадськістю. Визнанням істотного значення наукових розробок професора С. Качараби для розвитку історичної науки стало його відзначення Нагрудним знаком “За наукові досягнення” (2008), почесним званням “Заслужений професор Львівського національного університету імені Івана Франка” (2017).

3 роси і води, Вам, шановний і дорогий Степане Петровичу, на многії і благії літа!

\footnotetext{
${ }^{44}$ Степан Качараба, “Греко-католицька церква у США наприкінці XIX - на початку XX ст.: проблеми становлення,” Украӥна: культурна спадщина, національна свідомість, державність 21 (2012): 361-369; Степан Качараба, “Грецька незалежна церква в Канаді: метаморфози обрядового і релігійного характеру," Матеріали Міжнародної наукової конферениії "Реформаџія як суспільне явище: український вимір”, Львів 3-4 жовтня 2017 року (Львів, 2018), 160-179.

${ }^{45}$ Степан Качараба і Юрій Киричук, “Українська діаспора,” Довідник з історії Украӥни (Київ: Генеза, 1999), т 3, 408-409; Степан Качараба, "Еміграція," Довідник з історії України (Київ: Генеза, 2001), 230-233; Степан Качараба, “Еміграція,” Історія Украйни. Енциклопедичний довідник з історії Украӥни, видання 3-є (Київ: Генеза, 2008), 379-382.
} 
ISSN 2078-6077. Наукові зошити історичного факультету Львівського університету. 2018-2019. Випуск 19-20. Proceedings of History Faculty of Lviv University. 2018-2019. Issue 19-20.

\title{
"IN THE LIFE OF SCIENTIST MAIN BIOGRAPHICAL FACTS ARE BOOKS": REVIEW OF PROFESSOR STEPAN KACHARABA' SCIENTIFIC RESEARCHES
}

\author{
Ruslan SIROMSKYI \\ The Ivan Franko National University of Lviv, \\ Department of Modern and Contemporary History of Foreign Countries \\ 1 Universytetska str., 79000, Lviv, Ukraine \\ e-mail: sir.ruslan@yahoo.com
}

The article examines the scientific achievements of Professor Stepan Kacharaba, authoritative researcher of the history of Ukrainian emigration, author of numerous scientific publications on the history of Ukraine, historical regional (local) studies and world history, including several monographs.

The formation of S. Kacharaba as a scientist began in the second half of the 1980-s and was associated with the preparation of a candidate's dissertation devoted to Ukrainian emigration from Halychyna and Northern Bukovyna in the late $19^{\text {th }}$ and early $20^{\text {th }}$ centuries. A profound influence on the formation of the scientific outlook of a young researcher was made by Professor Stepan Makarchuk, who became the scientific supervisor of the candidate's degree, and subsequently as a consultant to Stepan Petrovych at the writing of his doctoral dissertation. The latter was concerned with the emigration processes in Western Ukraine during the interwar period, thus becoming a logical continuation of previous scientific research.

In general, among the issues raised in the research of scholarly problems, it is necessary to highlight the following aspects, such as the directions of emigration from the western Ukrainian lands, the emigration policy and the legislation of the countries of settlement of Ukrainians (USA, Canada, Brazil, Argentina), organization of the emigration policy in Lviv and Western Ukraine in general, public welfare on emigrants, agitation of potential emigrants, creation of the image of a country-settlement the attitude towards emigration among political parties and movements in Halychyna, etc. The problem of adaptation and promotion of entry into a new society is another aspect of the research interests of Professor S. Kacharaba. A notable scientific value was the discovery for the public of the diary of a peasant from Pokuttia, Ivan Dorundiak, in which he described his journey in 1895 to Canada.

The scientific climb S. Kacharaba is connected with the historical faculty of Lviv University, where he has passed all stages of scientific and pedagogical careers. Scientific and organizational activity of S. Kacharaba includes the position of deputy dean of the Faculty of History (1990-1994), the head of the Chair of Historical Area Studies (1998-2008) and the Head of the Chair of Modern and Contemporary History of Foreign Countries of the Lviv University (since 2008). Together with colleagues, S. Kacharaba developed theoretical foundations of historical regional (local) studies, outlining the further vectors of its development. Together with the staff of the Chair of Modern and Contemporary History of Foreign Countries, the scientist has prepared training materials for students of the Faculty of History.

Professor S. Kacharaba paid a lot of attention and effort to training pedagogical and scientific personnel. The results of Stepan Petrovych's research were recognized by scientists and the public.

Keywords: dissertation, history of emigration, local history, monograph, history of foreign countries.

\section{REFERENCES}

Baran, Zoia, Stepan Kacharaba, Ruslan Siromskyi ta Bohdan Chuma. Istoriia krain Zakhidnoi Yevropy ta Pivnichnoi Ameryky Novoho chasu (kinets XV-pochatok XIX st.: navchalnyi posibnyk. Red. Zoia Baran. Kyiv: Znannia, 2015. (in Ukrainian).

Dashkevych, Yaroslav. Postati: Narysy pro diiachiv istorii, polityky, kultury. Lviv: Lvivske viddilennia IUAD im. M. S. Hrushevskoho NANU, LNU imeni Ivana Franka, 2006. (in Ukrainian). 
ISSN 2078-6077. Наукові зошити історичного факультету Львівського університету. 2018-2019. Випуск 19-20. Proceedings of History Faculty of Lviv University. 2018-2019. Issue 19-20.

Horak Roman, Yavorivskyi Zinovii, Kacharaba Stepan i Kucheruk Vasyl. Yosyp Oleskiv. Zhyttia i diialnist. Lviv: Vyd-vo "Proman”, 2014. (in Ukrainian).

Hronskyi, Yosyp. Narys istorii Yavorivshchyny. Nauk. red. Viktor Holubko, Stepan Kacharaba ta Alla Serediak. Drohobych: Kolo, 2008. (in Ukrainian).

Holubko, Viktor, Stepan Kacharaba ta Alla Serediak. Istorychne kraieznavstvo. Navchalnyi posibnyk. Lviv: LNU imeni Ivana Franka, 2006, ñh. 1. (in Ukrainian).

Istorychnyi fakultet Lvivskoho natsionalnoho universytetu imeni Ivana Franka (19402000). Yuvileina knyha. Uporiadnyky Oleksii Vinnychenko i Oleksandr Tseluiko, vidpovidalnyi za vypusk Roman Shust. Lviv: LNU imeni Ivana Franka, 2000. (in Ukrainian).

Kacharaba, Stepan i Yaroslav Komarnytskyi. Vasyl Mudryi-hromadskyi diiach, polityk, publitsyst. Drohobych: Redaktsiino-vydavnychyi viddil DDPU imeni Ivana Franka, 2009. (in Ukrainian).

Kacharaba, Stepan i Yurii Kyrychuk. "Ukrainska diaspora.” Dovidnyk z istorii Ukrainy. Kyiv: Heneza, 1999, t. 3. 408-409. (in Ukrainian).

Kacharaba, Stepan i Stepan Movchan. "Emihratsiia halytskykh selian v Bosniiu i Hertsehovynu naprykintsi Õ² Õ - na pochatku ÕÕ st.” Problemy slovianoznavstva 42 (1990): 66-73. (in Ukrainian).

Kacharaba, Stepan i Mykola Rozhyk. Ukrainska emihratsiia (1890-1914 rr.). Emihratsiinyi rukh zi Skhidnoi Halychyny ta Pivnichnoi Bukovyny u 1890-1914 rr. Lviv: b.v., 1995. (in Ukrainian).

Kacharaba, Stepan i Ruslan Siromskyi. Istoriia Zakhidnoi Yevropy ta Ameryky druhoi polovyny $\tilde{O} \tilde{O}$ - pochatku ÕOI st.: praktykum. Lviv: LNU imeni Ivana Franka, 2015. (in Ukrainian).

Kacharaba, Stepan. "Brazyliiskyi harazd" Andriia Chaikovskoho: istorychna realnist chy khudozhnii vymysel?” Visnyk Lvivskoho universytetu. Seriia istorychna 48 (2013): 104114. (in Ukrainian).

Kacharaba, Stepan. "Diialnist hreko-katolytskoho dukhovenstva sered sezonnykh emihrantiv u Nimechchyni (1900-1914)." Visnyk Lvivskoi komertsiinoi akademii. Seriia “Humanitarni nauky" 10 (2011): 188-196. (in Ukrainian).

Kacharaba, Stepan. "Do pytannia pro emihratsiiu z Drohobytskoho povitu naprykintsi Õ $\mathrm{O}_{-}$ pochatku ÕÕ st.” Drohobytskyi kraieznavchyi zbirnyk. Spetsvypusk 3 (2017): 82-90. (in Ukrainian).

Kacharaba, Stepan. "Dokumenty TsDIA Ukrainy u Lvovi pro emihratsiiu iz Zakhidnoi Ukrainy u Frantsiiu (1919-1939)." "Istorychni pamiatky Halychyny". Materialy II naukovoi kraieznavchoi konferentsii 21 lystopada 2002 r. Lviv: LNU imeni Ivana Franka, 2003. 55-66. (in Ukrainian).

Kacharaba, Stepan. "Dokumenty TsDIA Ukrainy u Lvovi pro suspilnu opiku Hreko-katolytskoi tserkvy nad ukrainskoiu emihratsiieiu u Brazylii ta Arhentyni (kinets XIX - pochatok ÕÕ st.)." Istorychni pamiatky Halychyny. Materialy V naukovoi kraieznavchoi konferentsii 12 lystopada 2011 r. Lviv: LNU imeni Ivana Franka, 2011. 203-212. (in Ukrainian).

Kacharaba, Stepan. "Dokumenty TsDIA Ukrainy u Lvovi pro ukrainsku emihratsiiu do Brazylii naprykintsi XIX - na pochatku XX st." "Istorychni pamiatky Halychyny" (Do 150-richchia vid dnia narodzhennia Ivana Franka). Materialy IV naukovoi kraieznavchoi konferentsii 10 lystopada 2006 r. Lviv: LNU imeni Ivana Franka, 2008. 378-386. (in Ukrainian).

Kacharaba, Stepan. "Dushpastyrska opika Hreko-katolytskoi tserkvy nad ukrainskoiu emihratsiieiu u Bosnii ta Hertsehovyni (kinets XIX - pochatok XX st.)." Visnyk Lvivskoho universytetu. Seriia istorychna 49 (2013): 130-143. (in Ukrainian). 
ISSN 2078-6077. Наукові зошити історичного факультету Львівського університету. 2018-2019. Випуск 19-20. Proceedings of History Faculty of Lviv University. 2018-2019. Issue 19-20.

Kacharaba, Stepan. "Ekspozytura Emihratsiinoho upravlinnia u Lvovi v systemi polskykh emihratsiinykh instytutsii.” Lwów: miasto - społeczeństwo - kultura 7 (2010): 157-167. (in Polish).

Kacharaba, Stepan. “Ekspozytura Emihratsiinoho uriadu u Lvovi (1923-1932).” Lwów: miasto społeczeństwo - kultura 4 (2002): 333-345. (in Polish).

Kacharaba, Stepan. "Emigracia sezonowa galiciyskich i bukowińskich robotników rolnych do Niemiec." Chlopi, naród, kultura 5 (1997): 201-211. (in Polish).

Kacharaba, Stepan. "Emigracja Żydów z Ukrainy Zachodniej do Stanów Zjednoczonych w latach 1919-1939." Świat niepożegnany: Żydzi na dawnych ziemiach wschodnich Rzeczypospolitej $w$ XVIII-XX wieku: praca zbiorowa. Pod redakcją Krzysztofa Jasiewicza. Warszawa: Instytut Studiów Politycznych PAN, 2004. 77-87. (in Polish).

Kacharaba, Stepan. "Emihratsiia halytskykh selian v Rosiisku imperiiu v kintsi XIX st." Ukrainskyi istorychnyi zhurnal 9(1990): 30-36. (in Ukrainian).

Kacharaba, Stepan. "Emihratsiia naselennia Zakhidnoi Ukrainy v Arhentynu (1919-1939)." Naukovi zoshyty istorychnoho fakultetu Lvivskoho universytetu 4 (2001): 184-196. (in Ukrainian).

Kacharaba, Stepan. "Emihratsiia yevreiv iz Zakhidnoi Ukrainy v Arhentynu (1919-1939)." Naukovi zapysky Ternopilskoho derzhavnoho pedahohichnoho universytetu im. V. Hnatiuka. Seriia: Istoriia 13 (2001): 135-142. (in Ukrainian).

Kacharaba, Stepan. "Emihratsiia yevreiv iz Zakhidnoi Ukrainy v Palestynu u 1919-1939 rokakh." Ukraina Moderna 7 (2002): 119-140. (in Ukrainian).

Kacharaba, Stepan. "Emihratsiia z Poliskoho voievodstva (1919-1939). " Shliakhamy istorii. Naukovyi zbirnyk istorychnoho fakultetu LNU im. Ivana Franka na poshanu profesora Kostiantyna Kondratiuka. Uporiadnyk Oleksii Sukhyi. Lviv: Vydavnytstvo "Piramida", 2004. 348-364. (in Ukrainian).

Kacharaba, Stepan. "Emihratsiia.” Dovidnyk z istorii Ukrainy. Kyiv: Heneza, 2001. 230-233. (in Ukrainian).

Kacharaba, Stepan. "Emihratsiia." Istoriia Ukrainy. Entsyklopedychnyi dovidnyk z istorii Ukrainy. Vydannia 3-ye. Kyiv: Heneza, 2008. 379-382. (in Ukrainian).

Kacharaba, Stepan. "Emihratsiina polityka Polshchi ta yii realizatsiia u Volynskomu voievodstvi (1921-1939 rr.)." Volynska trahediia: cherez istoriiu do porozuminnia. Materialy Vseukrainskoi naukovoi konferentsii, m. Lutsk, 19-20 chervnia 2013 roku. Lutsk: Skhidnoievropeiskyi natsionalnyi universytet im. Lesi Ukrainky, 2013. 128-139. (in Ukrainian).

Kacharaba, Stepan. "Emihratsiina polityka Polshchi ta yii realizatsiia na Zakhidnii Ukraini (1919-1939)." Problemy slovianoznavstva 52 (2002): 73-86. (in Ukrainian).

Kacharaba, Stepan. "Emihratsiina polityka Polshchi u mizhvoiennyi period." Naukovi zoshyty istorychnoho fakultetu Lvivskoho universytetu 1 (1997): 103-105. (in Ukrainian).

Kacharaba, Stepan. "Emihratsiina polityka polskoho uriadu shchodo yevreiv u 1919-1939 rr." Poliaky, ukraintsi, bilorusy, lytovtsi u mizhvoiennii Polshchi (1921-1939). Materialy mizhnarodnoi naukovoi konferentsii, Drohobych, 8-9 zhovtnia 2004 r. Drohobych, 2005. 52-63. (in Ukrainian).

Kacharaba, Stepan. "Emihratsiini orhany Polshchi na Zakhidnii Ukraini (1919-1939 rr.)." Naukovi zapysky Natsionalnoho universytetu "Ostrozka akademiia": Istorychni nauky 2 (2002): 96-105. (in Ukrainian). 
ISSN 2078-6077. Наукові зошити історичного факультету Львівського університету. 2018-2019. Випуск 19-20. Proceedings of History Faculty of Lviv University. 2018-2019. Issue 19-20.

Kacharaba, Stepan. "Emihratsiinyi Dim u Lvovi." Lviv - misto - suspilstvo - kultura 3 (1999): 513-517. (in Ukrainian).

Kacharaba, Stepan. "Etapy emihratsii yevreiv iz Zakhidnoi Ukrainy v Palestynu u 1919-1939 rr." Drohobytskyi kraieznavchyi zbirnyk. Spetsvypusk do 60-richchia UPA (2002): 326-339. (in Ukrainian).

Kacharaba, Stepan. "Etnodemohrafichnyi rozvytok Halychyny za umov avstriiskoho panuvannia." Halychyna: etnichna istoriia. Red Stepan Makarchuk. Lviv: LNU imeni Ivana Franka, 2008. 116-130. (in Ukrainian).

Kacharaba, Stepan. "Hazeta "Chwila" yak dzherelo do vyvchennia emihratsii yevreiv iz Zakhidnoi Ukrainy v Palestynu." Aktualni problemy derzhavnoho upravlinnia 6 (2001): 310-319. (in Ukrainian).

Kacharaba, Stepan. "Hazeta "Ukrainskyi emihrant" yak litopysets emihratsii iz Zakhidnoi Ukrainy." Materialy naukovoi kraieznavchoi konferentsii "Istorychni pamiatky Halychyny”. Lviv: LNU imeni Ivana Franka, 2001. 64-70. (in Ukrainian).

Kacharaba, Stepan. "Hreko-katolytska tserkva u SShA naprykintsi XIX - na pochatku XX st.: problemy stanovlennia." Ukraina: kulturna spadshchyna, natsionalna svidomist, derzhavnist 21: (2012): 361-369. (in Ukrainian).

Kacharaba, Stepan. "Hreko-katolytska tserkva u stavlenni do ukrainskoi emihratsii z Halychyny naprykintsi XIX - na pochatku XX st.” Visnyk Lvivskoho universytetu. Seriia istorychna 46 (2011): 116-130. (in Ukrainian).

Kacharaba, Stepan. "Hretska nezalezhna tserkva v Kanadi: metamorfozy obriadovoho i relihiinoho kharakteru." Materialy Mizhnarodnoi naukovoi konferentsii "Reformatsiia yak suspilne yavyshche: ukrainskyi vymir.” Lviv 3-4 zhovtnia 2017 roku. Lviv, 2018. 160-179. (in Ukrainian).

Kacharaba, Stepan. "Ievreiska emihratsiia v politytsi polskoho uriadu u 1919-1939 rr." Naukovyi visnyk Chernivetskoho universytetu. Istoriia. Politychni nauky. Mizhnarodni vidnosyny 272. (2005): 143-149. (in Ukrainian).

Kacharaba, Stepan. "Immihratsiina polityka Kanady ta yii vplyv na ukrainsku emihratsiiu z Polshchi (1919-1939 rr.).” Pytannia istorii Ukrainy 5 (2002): 91-96. (in Ukrainian).

Kacharaba, Stepan. "Lvivske predstavnytstvo Varshavskoho emihratsiinoho upravlinnia (1923-1932)." Visnyk Lvivskoi komertsiinoi akademii. Seriia "Humanitarni nauky" 4 (2002): 124-132. (in Ukrainian).

Kacharaba, Stepan. "Lvivskyi viddil Yevreiskoho tsentralnoho emihratsiinoho tovarystva "JEAS" (1924-1939)." Problemy humanitarnykh nauk. Naukovi zapysky DDPU 9 (2002): 172-182. (in Ukrainian).

Kacharaba, Stepan. "Napriamky ukrainskoi emihratsii zi Skhidnoi Halychyny i Pivnichnoi Bukovyny naprykintsi XIX - na pochatku XX st." Visnyk Lvivskoho universytetu. Seriia istorychna 33 (1998): 114-121. (in Ukrainian).

Kacharaba, Stepan. "Nimetska emihratsiia iz Zakhidnoi Ukrainy u mizhvoiennyi period (19191939 rr.)." Nimtsi v istorii Volyni. Materialy Mizhnarodnoi naukovo-praktychnoi konferentsii. Lutsk, 1-2 zhovtnia 2015 r. Lutsk: PK "Tverdynia", 2016. 212-218. (in Ukrainian).

Kacharaba, Stepan. "Nimetska emihratsiia z Volynskoho voievodstva (1919-1939)." Visnyk Lvivskoho universytetu. Seriia istorychna 51 (2015): 265-274. (in Ukrainian).

Kacharaba, Stepan. "Opovidannia i chutky pro emihratsiiu v Halychyni naprykintsi XIX - na pochatku XX st.” Narodoznavchi zoshyty 2 (1999): 150-153. (in Ukrainian). 
ISSN 2078-6077. Наукові зошити історичного факультету Львівського університету. 2018-2019. Випуск 19-20. Proceedings of History Faculty of Lviv University. 2018-2019. Issue 19-20.

Kacharaba, Stepan. "Osnovni rysy ukrainskoi trudovoi emihratsii kintsia XIX - pershoi tretyny XX st." Zarobitchanstvo yak vybir maibutnoho: problemy sotsialno-psykholohichnoi adaptatsii ditei, batky yakykh perebuvaiut na zarobitkakh za kordonom. Lviv, 2004. 78-88. (in Ukrainian).

Kacharaba, Stepan. "Pisliamova." Mykhajlo Vasylyk. Ukraintsi Arhentyny: istoriia ta suchasnist. Lviv: Vyd-vo Ukrainskoho Katolytskoho Universytetu, 2009. 248-255. (in Ukrainian).

Kacharaba, Stepan. "Polska emihratsiia iz Zakhidnoi Ukrainy do Brazylii u mizhvoiennyi period." Ukraina: kulturna spadshchyna, natsionalna svidomist, derzhavnist 21 (2015): 113-122. (in Ukrainian).

Kacharaba, Stepan. "Polska emihratsiia iz Zakhidnoi Ukrainy do SShA (1919-1939 rr.)." Ukraina - Yevropa - Svit. Mizhnarodnyi zbirnyk naukovykh prats. Seriia: Istoriia, Mizhnarodni vidnosyny 2 (2009): 90-99. (in Ukrainian).

Kacharaba, Stepan. "Polske emihratsiine tovarystvo u Lvovi (1927-1939 rr.)." Visnyk Lvivskoho universytetu. Seriia istorychna 34 (1999): 479-485. (in Ukrainian).

Kacharaba, Stepan. "Problema emihratsii v politychnii propahandi halytskoho moskvofilstva." Respublikanets 1 (1994): 28-31. (in Ukrainian).

Kacharaba, Stepan. "Problema yevreiskoi prabatkivshchyny v politychnii propahandi sionistskykh partii ta obiednan Zakhidnoi Ukrainy." Istoryko-kulturna spadshchyna Prykarpattia. Naukovyi zbirnyk na poshanu Petra Arsenycha z nahody yoho 70-richchia ta 45-richchia istoryko-kraieznavchoi diialnosti. Ivano-Frankivsk: Vyd-vo "Nova zoria", 2006. 513-525. (in Ukrainian).

Kacharaba, Stepan. "Rol morekhidnykh kompanii ta yikh ahentury v emihratsiinomu protsesi." Ukrainska emihratsiia. Istoriia i suchasnist. Materialy mizhnarodnykh naukovykh konferentsii prysviachenykh storichchiu emihratsii ukraintsiv do Kanady. Lviv, 1992. 47-58. (in Ukrainian).

Kacharaba, Stepan. "Rol moreplavnykh kompanii ta yikh ahentury v emihratsiinomu rusi na Zakhidnii Ukraini (1919-1939)." Visnyk Lvivskoho universytetu. Seriia istorychna 35-36 (2000): 274-285. (in Ukrainian).

Kacharaba, Stepan. "Sezonna emihratsiia halytskykh i bukovynskykh silskohospodarskykh robitnykiv do Nimechchyny." Visnyk Lvivskoho universytetu. Seriia istorychna 28 (1992): 57-66. (in Ukrainian).

Kacharaba, Stepan. "Sezonna emihratsiia iz Zakhidnoi Ukrainy v Nimechchynu (1919-1939)." Visnyk Lvivskoho universytetu. Seriia istorychna 38 (2003): 219-241. (in Ukrainian).

Kacharaba, Stepan. "Sezonna emihratsiia zi Skhidnoi Halychyny v Nimechchynu u pershii tretyni XX st." Ukraina: kulturna spadshchyna, natsionalna svidomist, derzhavnist 16 (2008): 207-217. (in Ukrainian).

Kacharaba, Stepan. "Shchodennyk Ivana Dorundiaka (Do istorii ukrainskoi emihratsii v Kanadu)." Visnyk Lvivskoho universytetu. Seriia istorychna 37, ch. 2 (2002): 128-172. (in Ukrainian).

Kacharaba, Stepan. "Shchodennyk Ivana Dorundiaka yak dzherelo do vyvchennia ukrainskoi emihratsii v Kanadu." "Istorychni pamiatky Halychyny". Materialy III naukovoi kraieznavchoi konferentsii 19 lystopada 2004 r. Lviv: LNU imeni Ivana Franka, 2005. 66-74. (in Ukrainian).

Kacharaba, Stepan. "Sotsialna kharakterystyka emihrantiv z Polshchi v Arhentynu u mizhvoiennyi period (1919-1939).” Narodoznavchi zoshyty 3 (2001): 433-439. (in Ukrainian). 
ISSN 2078-6077. Наукові зошити історичного факультету Львівського університету. 2018-2019. Випуск 19-20. Proceedings of History Faculty of Lviv University. 2018-2019. Issue 19-20.

Kacharaba, Stepan. "Stavlennia avstriiskoho uriadu do ukrainskoi emihratsii z Halychyny ta Bukovyny." Visnyk Lvivskoho universytetu. Seriia istorychna 29 (1993): 88-99. (in Ukrainian).

Kacharaba, Stepan. "Stavlennia yevreiskoi hromadskosti Lvova do problemy emihratsii v Palestynu (1919-1939)." Lviv: misto - suspilstvo - kultura 6 (2007): 523-535. (in Ukrainian).

Kacharaba, Stepan. "Suspilna opika Hreko-katolytskoi tserkvy nad ukrainskoiu emihratsiieiu v Bosnii ta Hertsehovyni (kinets XIX - pochatok XX st.)." Ukraina - Yevropa - Svit. Mizhnarodnyi zbirnyk naukovykh prats. Seriia: Istoriia, Mizhnarodni vidnosyny 5, ch. 2 (2011): 275-282. (in Ukrainian).

Kacharaba, Stepan. "Tovarystvo "Polska opika nad spivvitchyznykamy za kordonom" u Lvovi (1927-1939)." Istoryko-politychni problemy suchasnoho svitu 8 (2001): 110-118. (in Ukrainian).

Kacharaba, Stepan. "Trudova emihratsiia iz Zakhidnoi Ukrainy u Frantsiiu (1919-1939).” Halychyna 8 (2002): 95-107. (in Ukrainian).

Kacharaba, Stepan. "Trudova emihratsiia iz Zakhidnoi Ukrainy v Brazyliiu (1919-1939)." Naukovi zapysky Ternopilskoho derzhavnoho pedahohichnoho universytetu im. V. Hnatiuka. Seriia: Istoriia 1 (2003): 211-221. (in Ukrainian).

Kacharaba, Stepan. "Trudova emihratsiia iz Zakhidnoi Ukrainy v Kanadu (1919-1939).” Visnyk Lvivskoho universytetu. Seriia istorychna 37, ch. 1 (2002): 350-364. (in Ukrainian).

Kacharaba, Stepan. "Trudova emihratsiia z Rohatynshchyny (kinets XIX - pochatok XX st.)." Rohatynska zemlia: istoriia ta suchasnist. Materialy III naukovoi konferentsii 26 bereznia $2002 r$ Lviv, 2005. 147-156. (in Ukrainian).

Kacharaba, Stepan. "Trudova emihratsiia z Zakhidnoi Ukrainy: istoriohrafiia problemy." Mizhnarodni zviazky: naukovi poshuky i znakhidky 13 (2004): 328-337. (in Ukrainian).

Kacharaba, Stepan. "Trudova zakhidnoukrainska emihratsiia v kintsi XIX - na pochatku XX st.: pytannia istorychnoho analizu." Materialy mizhnarodnoi konferentsii "Emihratsia naselennia zakhidnoukrainskykh zemel do Pivnichnoi Ameryky na rubezhi XIX - XX st. yii rol v osvoienni Kanadskoho Zakhodu”. Chernivtsi, 1990. 72-75. (in Ukrainian).

Kacharaba, Stepan. "Uchast lvivian v orhanizatsii opiky nad emihrantamy (1921-1939)." Lwów: miasto - społeczeństwo - kultura 5 (2005): 397-407. (in Polish).

Kacharaba, Stepan. "Uchast morekhidnykh kompanii v orhanizatsii pereselennia zakhidnoukrainskoho selianstva v Latynsku Ameryku u mizhvoiennyi period (19181939 rr.)." Naukovi zoshyty istorychnoho fakultetu Lvivskoho universytetu 2 (1999): 169181. (in Ukrainian).

Kacharaba, Stepan. "Ukrainska emihratsiia z Halychyny v Arhentynu naprykintsi XIX - pershii tretyni XX st." Etnichna kultura ukraintsiv. Red Mykhailo Hlushko. Lviv: LNU imeni Ivana Franka, 2006. 82-91. (in Ukrainian).

Kacharaba, Stepan. "Vasyl Mudryi - redaktor chasopysu "Dilo" (1927-1935 roky)." Istorychna pamiat. Naukovyi zbirnyk 1 (2007): 78-85. (in Ukrainian).

Kacharaba, Stepan. "Vid svobody immihratsii do restryktsionizmu: vplyv zakonodavstva SShA na ukrainsku emihratsiiu naprykintsi XIX - pershii tretyni XX st." Visnyk Lvivskoho universytetu. Seriia istorychna 39-40 (2005): 300-314. (in Ukrainian).

Kacharaba, Stepan. "Vplyv Pershoi svitovoi viiny na emihratsiiu iz Zakhidnoi Ukrainy do SShA." Persha svitova viina u viiskovo-istorychnomu vymiri (do 100-richchia podii): Zbirka materialiv Mizhnarodnoho naukovoho forumu 26-28 chervnia 2014 r. Lviv: ASV, 2014. 66-68. (in Ukrainian). 
ISSN 2078-6077. Наукові зошити історичного факультету Львівського університету. 2018-2019. Випуск 19-20. Proceedings of History Faculty of Lviv University. 2018-2019. Issue 19-20.

Kacharaba, Stepan. "Vplyv Pershoi svitovoi viiny na emihratsiiu iz Zakhidnoi Ukrainy.” Persha ta druha svitovi viiny $v$ istorii liudstva (do 100-richchia pochatku Pershoi i 75-richchia pochatku Druhoi svitovykh voien): Monohrafiia. Nauk. red. Serhii Troian. Kyiv: DP "NVTs "Priorytety", 2014. 213-226. (in Ukrainian).

Kacharaba, Stepan. "Vplyv Varshavskoho emihratsiinoho syndykatu na emihratsiiu iz Zakhidnoi Ukrainy (1930-1939)." Naukovi zoshyty istorychnoho fakultetu Lvivskoho universytetu 5-6 (2003): 204-210. (in Ukrainian).

Kacharaba, Stepan. "Vplyv zakonodavstva Arhentyny na emihratsiiu z Zakhidnoi Ukrainy (1919-1939 rr.)." Efektyvnist derzhavnoho upravlinnia. Zbirnyk naukovykh prats Lvivskoho rehionalnoho instytutu derzhavnoho upravlinnia Natsionalnoi Akademii derzhavnoho upravlinnia pry prezydentovi Ukrainy 5 (2004): 139-146. (in Ukrainian).

Kacharaba, Stepan. "Vplyv zakonodavstva Brazylii na emihratsiiu iz Zakhidnoi Ukrainy(19191939)." Pytannia istorii Ukrainy. Zbirnyk naukovykh statei kafedry istorii Ukrainy Chernivetskoho natsionalnoho universytetu imeni Yuriia Fedkovycha 6 (2003): 144148. (in Ukrainian).

Kacharaba, Stepan. "Vplyv zakonodavstva Kanady na ukrainsku trudovu emihratsiiu z Polshchi (1919-1939)." Aktualni problemy derzhavnoho upravlinnia 5 (2001): 282-291. (in Ukrainian).

Kacharaba, Stepan. "Vplyv zakonodavstva SShA na ukrainsku emihratsiiu (1919-1939 rr.)." Pytannia istorii Ukrainy 4 (2000): 170-175. (in Ukrainian).

Kacharaba, Stepan. "Z Halychyny do Ameryky: podorozh ukrainskoho emihranta (kinets XIX - pochatok XX st.).”Lwów: miasto - społeczeństwo - kultura 9 (2014): 136-144. (in Ukrainian).

Kacharaba, Stepan. "Zakonodavstvo Brazylii shchodo ukrainskoi emihratsii z Halychyny naprykintsi XIX - pershii tretyni XX st." Mizhnarodni zviazky: naukovi poshuky $i$ znakhidky 16(2007): 203-216. (in Ukrainian).

Kacharaba, Stepan. Emihratsiia z Zakhidnoi Ukrainy (1919-1939). Lviv: LNU imeni Ivana Franka, 2003. (in Ukrainian).

Kacharaba, Stepan. Emihratsiia z Zakhidnoi Ukrainy. 1919-1939. Avtoref. dys. dokt. ist. nauk. Instytut ukrainoznavstva im. I. Krypiakevycha, Instytut narodoznavstva NAN Ukrainy, 2003. (in Ukrainian).

Kacharaba, Stepan. Ukrainska emihratsiia zi Skhidnoi Halychyny i Pivnichnoi Bukovyny v kintsi XIX-na pochatku XX st. Teksty lektsii. Lviv, 1992, ch. 1-2. (in Ukrainian).

Kacharaba, Stepan. Ukrainska trudova emihratsiia iz Skhidnoi Halychyny i Pivnichnoi Bukovyny naprykintsi XIX - pochatku XX st. (1890-1914 rr.). Avtoref. dys. kand. ist. nauk. Lvivskyi derzhavnyi universytet imeni Ivana Franka, 1990. (in Ukrainian).

Kondratiuk, Kostiantyn. Spomyny i rozdumy istoryka. Lviv: LA "Piramida”, 2014. (in Ukrainian).

Kupyn, Lesia. "Kacharaba Stepan Petrovych." Encyclopedia. Lvivskyi natsionalnyi universytet imeni Ivana Franka: $v 2$ t. Lviv: LNU imeni Ivana Franka, 2011, t. 1. 591-592. (in Ukrainian).

Makarchuk, Stepan. Pobachene, pochute, perezhyte: Memuarni miniatiury. Kyiv: Atika, 2015. (in Ukrainian).

Prohrama z kursu "Novitnia istoriia krain Zakhidnoi Yevropy i Ameryky (1918 - pochatok XXI st.)." Ukladachi Stepan Kacharaba, Hennadii Kyparenko, Stepan Movchan, Ruslan Siromskyi, Mykhailo Shvahuliak. Lviv: LNU imeni Ivana Franka, 2010. (in Ukrainian). 